\title{
KEMUNGKINAN PROSA BUBUKSAH SEBAGAI SASTRA LUAR KERATON
}

\author{
Oleh: Bambang Sulistyanto
}

\section{I}

Cerita Bubuksah adalah karya sastra berbentuk prosa. Naskah asli (manuscript) diketahui hanya berjumlah dua buah. ditulis dalam bahasa Jawa-pertengahan dengan menggunakan huruf Bali (Pigeaud. 1968:68). Kedua naskah tersebut sampai sekarang masih disimpan dalam koleksi perpustakaan Universitas Leiden dan belum pernah diterbitkan. baik dalam bentuk cetakan maupun terjemahan, sehingga praktis belum banyak diketahui isinya.

Namun demikian, garis besar cerita yang terkandung di dalamnya telah dapat dikenal berkat laporan Poerbatjaraka yang telah disebarluaskan oleh van Siein Callenfels dalam kaitannya dengan ulasan terhadap relief-relief di dinding batur pendopo candi Parataran (Callenfels, 1919: 351-359).

Cerita Bubuksah mengkisahkan tentang pertedaan cara bertapa dua manusia bersaudara untuk memperoleh kelepasan. Dalam usahanya mendapatkan kesempurnaan tertinggi tersebut, jalan yang mereka tempuh berbeda dan bahkan bertentangan. Tokoh Gagang-aking sebagai saudara sulung, beriapa dengan cara terbatas heinya makan tumbuh-tumbuhan seperluniya saja. Sebaliknya takoh Bubuksah sebagai saudarabungsu, bertapa dengan memakan apa saja yang dapat dimakan, termasuk binatang dar bahkan manusia yang tertangkäp dalam jeratnya.

Meskipun sampai kini naskah Bubuksah diketahui hanya berjumlah dua buah, nampaknya cerita ini pernah populer di Jawa dan Bali. Bahkan sampai sekarang cerita ini masih terdengar hidup dalam tradisi di Bali. Versi prosa itu sendiri merupakan bukti bahwa sebuah lakon tanpa mutu tinggi tidak mungkin dapat dipindahkan 
ke dalam bentuk relief percandian. Cerita Bubuksah dipahatkan di pendopo candi Panataran dan candi Surawana. Candi Panataran merupakan kuil kenegaraan Majapahit, pada dinding tempat relief Bubuksah dipahatkan terdapat angka tahun 1297 C atau $1375 \mathrm{M}$ (Satyawati Suleiman, tt: 2).

Dalam kaitan dengan hal itu, tulisan ini akan mencoba mengungkapkan salah satu hal yang paling mendasar dalam sebuah penciptaan karya sastra, yaitu masalah kurun waktu penulisan.

Sebagian besar pengarang sastra Jawa Kuno sejauh diketahui merupakan pujangga keraton, meskipun tidak semuanya termasuk anggota keluarga raja atau keluarga bangawan. Namun demikian, mereka tergolong kalangan pejabat, petugas dan hamba yang mengelilingi sang raja dan banyak di antaranya juga memegang suatu jabatan religius (Zoetmulder, 1983:.182). Dalam kalangan dan suasana semacam itulah karya sastra diciptakan.

Bertolak dari masalah itu, tulisan ini akan mencoba pula mengungkapkan latar belakang sosial dari kalangan masyarakat yang melahirkannya. Artinya, apakah prosa Bubuksah dilahirkan oleh pujangga kalangan keraton atau sebaliknya dari kalangan luar-keraton.

Oleh karena naskah Bubuksah itu sendiri hingga kini belum pernah diterbitkan dalam bentuk cetakan maupun terjemahan, maka sebagai dasar kajian ini hanya dibatasi pada ringkasan cerita sebagaimana yang disajikan oleh van Stein Calenvels (1919: 348 - 361). Diakui bahwa sumber data yang dipergunakan sangat lemah dan kurang memadai, oleh karena itu interpretasi yang diajukan di sini perlu sekali untuk selanjutnya dikaji dengan penelitian-penelitian yang lebih mendalam, dengan menggunakan data lain dan dari sudut pandangan lain. 


\section{Tinjauan Filologi}

Karya sastra diciptakan oleh seniman untuk dinikmati, dipahami dan dimanfaatkan oleh masyarakat luas. Seniman itu sendiri adalah anggota masyarakat. Dalam pengertian ini, kehidupan yang terjalin akan mencakup hubungan masyarakat dengan orang seorang, antar manusia dengan manusia, dan juga antar peristiwa-peristiwa yang terjadi dalam batin seseorang. Dengan demikian peristiwa yang terekam oleh seniman, yang selanjutnya tervisualisasikan dalam bentuk karya sastrá, adalah hasil hubungannya dengan masyarakat (Sapardi Joko Damono, 1979: 1-6).

Telah menjadi kesepakatan, bahwa kitab-kitab kuno dapat diperlakukan sebagai surnber pemahaman sejarak. Meskipun penelitian terbaru inampu memberikan bukti bahwa iidak semua karya sastra merupakan cermin utuh keadaan masyarakat sezaman, namun se tidak-tidaknya dari ungkapar yang disampaikan, sastra itu sendiri dapat dijadikan petunjuk untuk mengetahui keadaan dan situasi masyarakat yang melahirkannya. Zoetmulder dalam penelitiannya tentang berbagai kakawin Jawa kuno telah mengemukakan hal yang senada, bahwa sekalipun cerita-cerita yang terkandung di dalam kitab-kitab tersebut berupa rekaan, namun hasil sastra itu sendiri dapat membuka jalan untuk lebih mendekati suatu kenyataan historis (Zoetmulder, 1983: 239).

Bertolak dari pandangan di atas, maka pentinglah artinya suatu karya sastra diketahui umurnya. Namun demikian, tidak mudah mengetahui usia suatu kitab kuno jika di dalam isi tidak terdapat keterangan-keterangan yang bisa dijadikan dasar untuk menelusurinya. Kesukaran ini kiranya dapat dibandingkan dengan kegiatan se orang widyapurbawan dalam usahanya mencoba merunut kronologi candi atau artefak lain yang tidak memiliki keterangan tertulis sebagaimana prasasti dan lain sebagainya. 
Kita belum tahu keadaan kitab Bubuksah, apakah di dalam teks naskahnya terdapat keterangan-keterangan seperti angka tahun, nama raja dan lain sebagainya, yang bisa dijadikan petunjuk untuk menentukan usia naskah. Hanya saja berdasarkan pengamatan Soewito Santosa melalui perbandingan gaya bahasa dengan kitab-kitab lain dikemukakannya, bahwa usia kitab Bubuksah sepantaran dengan usia kitab Tantu Panggelaran, namun lebih tua daripada kitab Korawasrama (Soewito Santosa, 1975: 119).

Pigeaud yang menggarap kita Tantu Panggelaran sebagai bahan disertasi, mengemukakan bahwa kitab tersebut ditulis sekitar tahun $1550-1635$ M (Pigeaud, 1924: 50). Pendapat ini didasarkan pada kolophon yang terdapat pada naskah seri A. Demikian pula kitab Korawasrama, berdasarkan pada bunyi kolophon yang terdapat pada naskah B, dapat ditentukan usia absolut kitab tersebut, yaitu tahun 1703 M (Swellengrebel, 1936: 41).

Bertolak dari keterangan di atas, maka dapatlah diperoleh gambaran bahwa masa penulisan kitab Bubuksah berkisar antara tahun $1550-1703$ M. Penentuan umur secara relatip sebagaimana diajukan oleh Soewito Santosa tersebut terasa sekali kurang tegas, yaitu mempunyai tenggang waktu yang cukup panjang sekitar 1,5 abad lebih. .

Namun demikian, jika naskah Tantu Panggelaran sebagaimana telah dilatinkan oleh Pigeaud itu disimak lebih dalam, maka akan dapat dijumpai keterangan yang menarik perhatian yang mungkin dapat membantu memperjelas usia naskah Bubuksah itu sendiri. Di dalam naskah Tantu Panggelaran, disebutkan pula nama Bubuksah dan Gagang-aking, keduanya adalah saudara yang sejak masih muda suka bertapa dan mereka berdua adalah anak dari Mpu Siddayogi.

"... mangkana pawkas bhataraçwara. Sang Siddayogi gègèr lwar ing Mayana, hlitan lwah lawan mpu Siddayogi. Tan ucapên lawasnya, manak ta sira kalih siki cami jalu, sang Gagangaking panuha, sang Bubuksah kang anom; pada nwam amiku pada lumakwa tapa sira," (Pigeaud, 1924: 89). 
Identitas tokoh Bubuksah dan Gagang-aking dalam Tantu Panggelaran di atas adalah serupa dengan yang terdapat dalam kitab Bubuksah. Dengan demikian dapatlah dipastikan, bahwa yang dimaksudkan dengan tokoh Bubuksah dan Gagang-aking di dalam kedua kitab tersebut masing-masing adalah tokoh yang sama.

Dari pandangan di atas terdapat dua kemungkinan yang perlu diajukan berkenaan dengan usia kitab Bubuksah. Pertama, dua naskah Bubuksah yang tersimpan di Leiden lebih tua usianya daripada kitab Tantu Panggelaran. Kedua, mungkin pula kitab Bubuksah itu sendiri sebenarnya sudah lama ada. Adapun penyebutan dua tokoh bersaudara dalam Tantu Panggelaran itu hanyalah berdasar pada cerita yang belum sempat dibukukan atau dari cerita yang dituturkan secara lisan saja. Dua kemungkinan di atas merupakan permasalahan yang menuntut penelitian lebih mendalam, khususnya dari bidang filologi. Namun demikian akan tetap dicoba pula memecahkannya melalui pendekatan data arkeologik.

\section{Tinjauan Arkeologi}

Data arkeologi yang dipergunakan sebagai pembantu untuk memecahkan permasalahan di atas adalah batur pendopo Penataran, yaitu tempat relief Bubukşah dipahatkan. Pada batur pendopo Penataran ini terdapat angka tahun 1297 C (Satyawati Suleiman, tt:2), hal itu berarti pendopo tersebut dibangun pada sekitar tahun $1297 \mathrm{C}$ atau $1375 \mathrm{M}$.

Jika kenyataan ini dikaitkan dengan usia kitab Bubukșah, yaitu paling tua harus sudah ditulis pada tahun $1550 \mathrm{M}$ atau pertengahan abad ke 16, maka akan terlihat adanya ketidaksesuaian waktu antara saat penulisan naskah dengan pertanggalan bangunan tempat cerita direliefkan (1375 M).

Nampaknya kasus perbedaan waktu, antara saat penulisan naskah dengan pertanggalan bangunan tempat cerita dipahatkan, seringkali dijumpai dalam dunia kepurbakalaan. Candi Jago dengan relief Kuñjarakarnạa misalnya, candi ini didirikan pada tahun $1268 \mathrm{M}$ 
(Krom, 1923: 95), sedangkan naskah kakawin Kuñjarakarnaa sendiri baru muncul pada pertengahan abad ke 14, zaman keemasan Majapahit (Zoetmulder, 1983: 476).

Sehubungan dengan adanya pertentangan waktu tersebut, maka Krom berpendapat, bahwa relief-relief candi belum dapat memberikan petunjuk yang mutlak untuk menentukan umur suatu karya sastra. Untuk menekankan pendapatnya itu, lebih jauh ia memberikan contoh berkenaan dengan relief Rāmãyana di candi Prambanan. Sampai sekarang belum ada ketentuan yang pasti, bahwa relief yang terdapat pada candi Siwa itu dapat memberikan bantuan untuk menentukan usia kakawin Rāmāyaṇa (Krom, 1916: 508).

Berkaitan dengan relief Bubukşah di pendopo candi Panataran, rupanya memang tidak harus berarti keduanya (antara relief dan naskah) sama, dalam pengertian berasal dari satu sumber. Terdapat kemungkinan, bisa saja sumbernya yang berlainan, dalam arti sumber untuk pemahatan relief bukan berasal dari naskah, melainkan dari cerita yang belum terbukukan.

Pandangan di atas jika dikaitkan dengan keterangan sebagaimana yang terdapat dalam naskah Tantu Panggēlaran, seperti dikutip di depan, memberikan petunjuk bahwa cerita Bubukşah sudah cukup tua usianya. Sehubungan dengan itu diajukan hipotesis, bahwa cerita tutur Bubukșah telah ada jauh sebelum masa penulisan kitab Tantu Panggëlaran dan sebelum masa pembangunan pendopo candi $\mathrm{Pa}$. nataran (1375 M), kemudian cerita itu baru sempat dibukukan pada sekitar pertengahan abad ke 16.

III

\section{Sastra tutur}

Ditinjau dari isi cerita, prosa Bubukșah lebih menonjolkan sifat didaktis, sehingga mungkin bisa dikatakan prosa ini lebih tepat jika digolongkan ke dalam sastra keagamaan daripada sastra murni. Cerita ini oleh beberapa sarjana ditafsirkan sebagai simbolisme 
dari perbedaan cara bertapa antara pendeta Siwa dan pendeta Budha (Callenfels, 1919: 359; Rassers, 1982: 61). Dalam hal ini Gagangaking yang sulung disamakan dengan pendeta Siwa, sedangkan tokoh Bubukșah yang bungsu diidentikkan dengan pendeta Budha.

Pendapat di atas nampaknya sesuai dengan pengamatan Pigeaud dari sisi pengelompokan karya sastra. Pigeaud dalam usahanya memberikan kerangka umum tentang klasifikasi kesusasteraan Jawa atas dasar isi yang dikaitkan dengan pandangan alam pikiran Jawa, menempatkan karya sastra Bubukșah ke dalam Jenis sastra agama dan kesusilaan yang sering disebut pula sebagai sastra tutur (Pigeaud, 1967: 71). Lebih jauh ditekannya, bahwa kitab tutur itulada yang bersifat Siwa dan bersifat Budha, dan biasanya dimiliki oleh para pemuka agama sebagai pedoman di dalam memberikan pelajaran kepada para siswanya (Ibid: 52 ).

Sifat sastra tutur pada umumnya bertujuan sebagai pendidikan moral (Ibid: 71). Demikian pula nampaknya berkenaan dengan prosa Bubukșah, yaitu dimaksudkan untuk memberikan penjelasan tentang jalan yang perlu ditempuh oleh manusia dalam usahanya memperoleh kelepasan. Dalam hal ini prosa Bubukșah memberikan simbol tentang perilaku kedua tokoh, yaitu Bubukșah (Budhis) dan Gagangaking (Siwais), yang masing-masing ditampilkan dalam konsep berbeda. Namun demikian sebagaimana sifat sastra tutur, pada akhir cerita ditunjukkan kebenaran yang paling baik di atas kebenaran lainnya.

Mengamati prosa Bubukșah, hampir tidak dapat dielakkan muncul kesan, bahwa cerita ini lebih menitikberatkan pada kebenaran Budhisme. Pandangan demikian mungkin ada benarnya, meskipun demikian tidak perlu dikembangkan menjadi semacam anggapan, bahwa prosa Bubukşah bertujuan untuk kegiatan propaganda agama Budha. Demikian pula prosa ini tidak dapat dianggap sebagai sindiran terhadap agama Hindu, apalagi dikaitkan dengan petunjuk adanya konflik rivalitas di antara kedua agama tersebut, sebab cerita Bubukşah dipahatkan pada batur pendopo Panataran dan candi Surawana 
yang tidak dapat disangkal berlatar belakang agama Siwa.

Dari uraian di atas, menjadi jelas bahwa pertama-tama prosa ini dimaksudkan sebagai sebuah karya yang mengutamakan unsur didaktis-moral. Lebih dalam ajaran moral tersebut berkaitan dengan sistem keagamaan yang berlaku pada waktu itu, yaitu simbolisme dari keakraban antar kedua agama: Siwa dan Budha.

\section{Sastra luar keraton}

Tetapi sebagaimana diketahui jumlah sarjana yang bekerja dalam bidang filologi sangat sedikit dan kurang memadai dengan luas lapangan yang ada, sehingga bisa dipahami, bahwa naskah Bubukşah masih lepas dari perhatian para ahli. Meskipun demikian, keadaan semacam itu perlu tetap disayangkan, sebab karya sastra Bubukșah dapat dipandang sebagai salah sebuah media yang dapat mengungkapkan berbagai aspek kehidupan sosial masyarakat pada waktu itu. Sebagai sumber sejarah, khususnya masalah keagamaan, prosa Bubukșah dapat disejajarkan dengan kakawin Sutasoma, Arjunawijaya atau Kuñjarakarna dan beberapa kakawin bersifat religius lainnya.

Yang dimaksudkan dengan sastra luar-keraton, adalah karya sastra yang dihasilkan oleh para pujangga di luar lingkungan budaya keraton. Adapun ciri-ciri yang membedakan antara sastra keraton dan sastra luar-keraton sampai sekarang belum ada perumusan secara mantab. Namun demikian, Edi Sedyawati (1985: 260-261) dalam usahanya mengungkapkan citra Ganesa melalui kajian beberapa karya sastra, memberikan tiga macam tanda untuk menetapkan suatu karya sastra sebagai hasil karya luar-keraton. Ketiga macam tanda tersebut yaitu:

1. Penggambaran lingkungan keadaan luar-keraton dengan menunjukkan keakraban si penulis dengannya

2. Penulis tidak memuji, menyebut ataupun menyatakan hubungan tertentu dengan seorang raja 
3. Penulis menyatakan diri sebagai seorang dari kalangan luar keraton.

Lebih jauh diberikannya contoh tentang karya sastra yang berkait dengan jenis petunjuk yang disebut terakhir tadi, yaitu misalnya kakawin Kuñjarakarna. Penulis kakawin ini menyebut dirinya sendiri sebagai mpu dusun dan kadi nwam dusun atau "guru desa" dan "seperti orang desa" (Ibid: 261). Demikian pula Teeuw dan Robson (1981: 46), menafsirkan bahwa pengarang kitab ini berasal dari kalangan keagamaan luar-keraton. Adapun untuk jenis petunjuk yang pertama dan kedua, oleh Edi Sedyawati diberikan contoh, misalnya diperlihatkan oleh kitab Tantu Panggēlaran dan Korawāsrama (Ibid).

Petunjuk yang diberikan oleh Edi Sedyawati di atas akan dicoba diterapkan sebagai dasar pengungkapan latar belakang sosial atau kalangan yang melahirkan prosa Bubukșah. Petunjuk-petunjuk di atas, sebenarnya masih dapat pula dilengkapi dengan beberapa ciri lainnya berdasarkan hasil kajian perbandingan pada berbagai karya sastra keraton dan sastra luar-keraton, seperti pada gaya penyajian, perbendaharaan kata dan lain sebagainya. Akan tetapi petunjuk di atas tidak semua dapat dipergunakan sebagai dasar kajian, sebab naskah Bubuksah belum ada yang menerbitkan dan masih tersimpan dalam koleksi perpustakaan Leiden dengan nomor kode 3918 dan 4164 (Pigeaud, 1968: 71). Belum pula diketahui, apakah naskah Bubukșah terdapat juga di dalam koleksi museum Kirtya, Bali.

Deskripsi tentang tempat-tempat yang terpantul dalam prosa Bubukșah, jelas menunjukkan lingkungan yang jauh bahkan tak tersentuh oleh suasana kerajaan. Pusat keagamaan kecil yang terletak di lereng Gunung, sebagai tempat tokoh Bubukșah dan Gagangaking menimba-ilmu dari seorang guru, menjadi latar belakang tempat serta fokus pembicaraan dalam prosa ini. Pelukisan mengenai suasana dan keadaan pedesaan di sini, tidak dimaksudkan sebagai pemaparan ilustrasi atau sekedar untuk menghidupkan pelukisan cerita sebagaimana sering terdapat dalam berbagai karya sastra, namun berkait dengan keutuhan cerita Bubukșah itu sendiri. 
Prosa Bubukșah merupakan cerita asli Jawa, nampaknya tidak perlu

diragukan

Nama Kebo-milih dan Kebo-ngraweg sebagai nama asli Bubukșah dan Gagang-aking sebelum diangkat menjadi murid oleh sang guru dari mandala Nguneng, jelas merupakan nama khas orang Jawa

Cerita ini pada hakekatnya mengkisahkan dua pemuda desa yang diusir orang-tuanya, kemudian menyepi di sebuah pertapaan di lereng Gunung. Menilik ikhtisar prosa Bubukşah, memang sama sekali tidak terdapat petunjuk adanya suatu pemerintahan kerajaan dan nama-nama para bangsawannya. Namun demikian hal ini bukan berarti di dalam teks aslinya tidak menyebut-nyebut nama kerajaan dan rajanya. Rupanya cerita ini hanya terbatas berbicara pada sekitar lingkungan pertapaan dengan penekanan pada perbedaan cara bertapa mereka berdua, sekaligus penjelasan kebenaran tertinggi di antara mereka selama melakukan tapa-brata.

Keadaan hutan yang sepi beserta isi flora dan faunanya dimanfaatkan oleh pengarang untuk memperjelas perbedaan watak tokoh Bubukșah dan tokoh Gagang-aking dalam usahanya memperoleh kamokșhan. Bubukșah digambarkan kerjanya setiap hari hanya mencari pohon aren untuk dijadikan tuak dan menjerat binatang-binatang liar. Tidak pernah berhenti ia minum tuak dan berpesta makan daging binatang maupun manusia yang tertangkap dalam jeratnya. Sebaliknya Gagang-aking, setiap hari menggarap ladang untuk ditanami berbagai macam sayuran khusus sebagai bahan makanannya seharihari. Perbedaan watak dan laku dari dua saudara yang berlatar. belakangan konsep keyakinan berbeda ini, ditampilkan dalam suasana kehidupan sehari-hari masyarakat pedesaan.

Di tangan pujangga yang belum dikenal inilah, cerita tentang pemburu, pemabuk, serta pemakan daging manusia, diubah menjadi cerita religius yang sangat menarik. Mulai dari perjalanan Bubukșah dan Gagang-aking mendaki lereng Gunung, membakar hutan, mendirikan pondok dan mempelajari kitab-kitab, serta berburu binatang, dilukiskan dengan sederhana tidak dibuat-buat, sehingga menampilkan kesan keakraban si pengarang dengan keadaan sekitar. 
Jika menilik cara penyampaian cerita yang demikian polos dan sederhana dalam usaha pengarang menyampaikan maksud ajaran yang terkandung di dalamnya, maka dapat diduga cerlta ind se. ngaja dikarang bukan untuk dipersembahkan kepada raja atau negara, melainkan untuk kepentingan rakyat biasa. Jika anggapan ini dapat disetujui maka kitab tutur Bubuksah perlu pula dibedakan dengan jenis tutur sang Hyang Kamahăyănikan. Masyarakat kebanyakan, kaum petani atau pekerja kasar lain misalnya, pasti merasa berat untuk memahami uraian yang berfilsafat tinggi dari tutur Sang Hyang Kamahãyānikan Akan tetapi berkenaan dengan lakon Bubukșah yang berbicara tentang pembakaran hutan, pemasangan jerat/perangkap binatang-binatang liar, atau seekor macan putih penjelmaan dewa yang bisa dinaiki ke surga, pada umumnya merupakan hidangan rokhani yang sederhana dan mudah ditangkap serta dimengerti oleh alam pikiran rakyat biasa. Memperhatikàn latar budaya yang jauh dari sentuhan lingkungan budaya keraton dan kenyataan bahwa tutur ini memberikan tekanan besar pada unsur pendidikan keagamaan untuk rakyat biasa, serta gaya penyajiannya yang sederhana, maka dapat diduga bahwa tutur ini dihasilkan olen suatu lembaga keagamaan atau pendidikan agama luar keraton.

Adanya tempat-tempat pendidikan di luar keraton pada periode Jawa Timur, tercermin pula dalam beberapa karya sastra maupun prasasti. Keberadaan biara atau pertapaan yang tercermin pada berbagai karya sastra tersebut, pada umumnya ditampilkan dalam kaitannya dengan kunjungan seorang tokoh, raja atau putera raja. Zoetmulder (1983: 257) melalui kajian berbagai kakawin Jawa kuno berhasil mencatat beberapa biara atau padepokan dengan aneka macam sebutan seperti: wanđśrama, patapan, pajaran, pangalusan, parhyangan, katyagan, dan lain sebagainya. Adapun biara-biara semacam itu, tempatnya selalu jauh dari perkotaan, di dalam naungan pemandangan alam pegunungan yang damai. $\mathrm{Di}$ tempat inilah seorang peserta melakukan samadi seorang diri, atau dengan sekelompok cantrik untuk ditempa di bawah bimbingan pertapa tua, dewa guru, kaki hyang, hyang atuha, atau wiku wrddha (Ibid: 257). 
Di dalam kakawin Siwarātrikalpa atau Lubdaka misalnya. ter dapat keterangan mengenai kadewagurwan atau padepokan pendidikan keagamaan. Kakawin yang ditulis oleh mpu Tanakung pada akhir Majapahit sekitar pertengahan abad XV ini menyebutkan, bahwa kadewagurwan tersebut terletak di tepi sungai yang tebingnya curam sekali dan di sekitarnya terdapat jurang-jurang dengan latar belakang perbukitan. Pada tembok gapuranya menjulang tinggi berwarna putih dibuat dari tanah liat (Teeuw, 1969: 71).

Sebuah kadewagurwan lainnya (Sumanasantaka XXXVIII. 5) terletak di kaki Gunung dan dihuni oleh keluarga dwija (brahmana) dengan wanita-wanitanya yang suci bersih.. Hal serupa dengan itu pada masa Singosari disebutkan pula dengan berbagai sebutan, seperti misalnya di dalam prasasti Mulamalurung dikenal dengan nama karşyan, yaitu tempat para resi (Edi Sedyawati, 1985: 318)... Masih banyak lagi sumber yang menerangkan tempat-tempat ke agamaan luar-keraton dengan berbagai macam sebutan yang berbeda.

Adapun pertapa yang tinggal di dalam sebuah biara di tengah hutan dikenal dengan sebutan wiku talun atau wiku dusun (Sumanasantaka VI. 2), sedangkan para rokhaniwan yang berdiam di dalam keraton disebut wiku nagara. Demikian pula berdasarkan beberapa sumber kakawin, terdapat perbedaan penamaan antara kawi keraton dan kawi luar-keraton. Kawi nagara, yaitu sebutan untuk seorang kawi keraton, sedangkan kawi wiku diperuntukkan khusus bagi kawi yang menjalani kehidupan religius. Sedangkan kawi sunya adalah kawi yang hidup sebagai pertapa menjauhkan diri di dalam sebuah biara (Zoetmulder, 1983: 87). Adanya berbagai macam istilah bagi tempat kegiatan keagamaan luar-keraton di atas, serta ditambah dengan kenyataan adanya berbagai istilah untuk kawi, maka menun. jukkan betapa semangatnya kehidupan keagamaan dan kepenyairan pada masa-masa itu. Berkaitan dengan hal itu, maka di tempattempat pendidikan keagamaan di luar keraton itu pulalah mungkin para kawi wiku atau kawi sunya melakukan aktivitas menulis ber bagai karya sastra. 
Sementara ini kita belum mempunyai data kuat, yang mungkin data ini terdapat di dalam teksnya sendiri, bahwa tutur Bubuksah diciptakan oleh pujangga luar-keraton, maka yang menarik perhatian adalah bahwa sastra tutur ini telah dipahatkan di dinding percandian kenegaraan, yakni di batur pendopo Panataran dan juga di candi Surawana. Kenyataan serupa dengan hal tersebut, terdapat pada candi Jago berkaitan dengan cerita dari kakawin Kuñjarakarṇa dan Pärthayajna.

IV

Sebagai penutup dapat dikemukakan beberapa hal sebagai berkut:

1. Cerita Bubuksah, baik yang terdapat di dalam karya sastra maupun yang tervisual dalam reliof candi, merupakan cermin kehidupan masyarakat sezaman.

2. Prosa Bubukşah meerupakan jenis sastra tutur yang diciptakan oleh pujangga luar-keraton, sebagai pendidikan moral yang khususnya diperuntukkan kepada masyarakat kebanyakan.

3. Perlu pula ditekakan, bahwa pentingnya prosa Bubukșah pertama-tama tidak disebabkan karena keunggulannya sebagai sebuah karya sastra, melainkan karena isinya mengandung ideide religius yang disampaikan melalui simbolisasi para tokoh utama.

Sayang sekali kitab ini belum mendapat penanganan khusus dalam aktivitas ilmiah. Mungkin di dalam teks naskahnya terdapat keterangan yang mampu menjawab berbagai persoalan yang telah dikemukakan di atas, termasuk di dalamnya pertanyaan, mengapa harus Bubuksah (Budhisme) yang lebih ditonjolkan daripada Gagangaking (Siwaisme). 


\section{ACUAN}

Edi Sedyawati, 1985. Pengarcaan Ganesa Masa Kadiri dan Singasari: Sebuah Tiniauan Seiarah Kesenian, Disertasi, Universitas Indonesia.

Krom, N.J. 1916. "Over de dateering van eenige kawi geschriften", TBG LVII. Batavia: Albrecht \& Co.

Krom, N.J, 1923. Inleiding tot de Hindoe-Javaansche Kunst II, 's.Hage: Martinus Niihoff.

Pigeaud, Th, G, Th, 1924, De Tantu Panggelaran, Een Oud. Javaansche porza geschrift ,'s-Gravenhage: Martinus Niihoff.

Pigeaud, Th, G. Th, 1867 - 1967 ,Literature of Jawa I dari II. Catalogue raisonne of Javanese manuscripts in the library of the University of Leiden and other public collections in the Netherlands. Leiden: The Hague, Martinus Niihoff.

Rassers, W.H, 1982, "Ciwa dan Budha di Kepulauan Indonesia", dalam Civa dan Budha. Seri teriemahan LIPI - KITLV Jakarta: Diambatan, $h / m, 35 \cdot 67$.

Sapardi Joko Damono, 1979. Sosiologi Sastra Sebuah Pengantar Ringkas, Jakarta: Pusat Pembinaan Dan Pengembangan Bahasa Departemen Pendidikan dan Kebudayaan.

Satyawati Suleiman, Batur Pendopo Panataran, Jakarta: Proyek Penelitian Purbakala.

Soewito Santosa, 1974. Sutasoma, A Study in Javanese Wairayana. New Delhi: International Academy of Indian Cultural.

Stein Callenfels, P.W, van, 1919, "Verklaring van Basrelief Series, De Bubuksah serie aan het pendopo-terras te Panataran", TBG LLVII, Batavia: Albrecht \& Co, hlm, 348 - 361.

Swelengrebel, J.L. Korawasrama, 1936, Een Javaansche Proza Geschrift, V.H. PA. Mees Santport.

Teeuw \& Robson, 1981, Kuniarakarma Dharmakathana. An old Javanese Poem Mpu Dusun, The Hague: Martinus Niihoff.

Teeuw \& Robson, et al. Siwara trikalpa of Mpu Tangkup. An Old Javanese poem, its Indian source and Balinese Illustrations. The Hague: Martinus Niihoff.

Zoetmulder, P.J, 1983, Kalangwan, Sastra Jawa Kuna Selayang Pandang. Teriemahan oleh Dick Hartoko, Jakarta: Diambatan. 